\title{
Exploring Vocational High School Students' Entrepreneurial Intention: Preliminary Study
}

\author{
Darma Rika Swaramarinda \\ Universitas Negeri Jakarta, Jakarta, Indonesia \\ https:// orcid.org/0000-0003-1588-4569
}

\author{
Badrul Isa, Norhayati Mohd Yusof and Mohd Ali Bahari Abdul Kadir \\ Universiti Teknologi MARA, Selangor, Malaysia \\ https:/ / orcid.org/0000-0002-7491-8223 \\ https://orcid.org/0000-0002-0244-3505 \\ https://orcid.org/0000-0002-9488-2547
}

\begin{abstract}
This paper presents an ongoing doctoral study exploring the entrepreneurial intention of pilot public vocational high school students in entrepreneurship development programs in Jakarta, Indonesia. This paper is a preliminary study that employed two methods of data collection, namely questionnaires and interviews. The method allows for triangulation of the data and to establish the reliability and validity of data. Due the Covid-19 pandemic, this study was conducted online to garner information from the participants. The discussion in this paper focuses on the data derived from a questionnaire. Using a purposive sampling method, open-ended questions were posed to 111 students and 60 alumni. Interviews were also conducted with three students using open-ended questions. Data were analyzed inductively by using thematic analysis. The five stages of Creswell's qualitative data analysis were used: arranging and preparing data; reading all data; coding the data; connecting the themes; and interpreting the meaning of those themes. The various themes and sub-themes from the questionnaires and interviews have identified several sub-themes. The findings of the study may be of interest to governments, schools, and researchers. The results will enable those parties to determine the entrepreneurial intention needed to prevent and reduce unemployment among vocational high school graduates.
\end{abstract}

Keywords: entrepreneurial intention; entrepreneurial self-efficacy; preliminary study; social support; vocational high school

\section{Introduction}

Unemployment is an issue concerning policymakers in both developed and developing countries. According to statistics from Asian Trading Economies 
(2020), Indonesia's unemployment rate is $4.99 \%$, higher than Thailand's $1 \%$, Vietnam's $2.15 \%$, and Singapore's $2.4 \%$.

The Indonesian government has been introducing policies on entrepreneurship education from primary schools to higher education in order to resolve and minimize the number of unemployed people in Indonesia, as well as to increase their entrepreneurial motivation, which they hope may lead to entrepreneurs who focus on creating employment (Mahendra et al., 2017). Marič et al. (2010) proposed that the encouragement of entrepreneurial thought leads to the creation of an entrepreneurial mindset. The governments of different countries must develop their own entrepreneurial economies.

A similar unemployment issue occurred in Hong Kong. School graduates who are unable to pursue tertiary education at universities or other institutions will almost certainly seek employment but there are not many career opportunities available for them. The Hong Kong government addressed the unemployment crisis by creating temporary jobs, but that has not always worked. As a result, entrepreneurship education is critical in a variety of ways (Cheung, 2016).

In order to address the problem of unemployment, awareness of or knowledge about entrepreneurial intention must be instilled in young people, beginning in the Indonesian school curriculum, especially at the vocational high school level. Therefore, the Indonesian government has made some efforts to promote students' entrepreneurial intentions (Genoveva, 2020), including entrepreneurship education regulations, which include:

a) Specifying that that entrepreneurship subjects are taught for two years in classes 11 and 12 for seven hours a week and eight hours a week, as stipulated by the Director-General of Basic Education and the Middle Ministry of Education and Culture's Regulation No.07/ D.D5/KK/2018 on the medium school curriculum framework for vocational school 2018 (MoEC, 2018).

b) A strategic Plan for the Ministry of Education and Culture, 2020-2024 (MoEC, 2020).

The Ministry of Education and Culture's strategies for improving students' job readiness include ensuring the development of technological skills, and emphasizing the development of soft skills, instilling work culture values, and teaching entrepreneurial skills in the vocational high school curriculum and vocational training. Thus, an improvement in the number of vocational education graduates who obtain employment and start a business within one year increases (MoEC, 2020).

However, the entrepreneurial intention among vocational high school students remains poor, as evidenced by the fact that only $8.22 \%$ of vocational high school graduates became entrepreneurs in February 2019 (Indonesian Central Statistics Agency, 2020). The regulations support entrepreneurship education, such as that entrepreneurship subjects are taught for seven to eight hours per week for vocational high school students but entrepreneurial intention is still low. This research is significant to discover the entrepreneurial intention amongst 
vocational high school students.

This is a working paper that aims to present a preliminary study exploring the entrepreneurial intention of vocational high school students in pilot public vocational high schools for entrepreneurship development programs. A population of 111 students in class 12, 60 alumni were surveyed, and three students were interviewed.

\section{Literature Review}

\subsection{Entrepreneurial Intention (EI)}

The researchers laid the theoretical groundwork for understanding entrepreneurship, which is the basis of this research. In research, and in daily life, readers often hear and use the word entrepreneurship. Entrepreneurship is described as the ability and willingness to extend, coordinate, and manage a commercial enterprise task, while taking on any associated risks in order to generate profit (Nguyen, 2020). Linan and Chen (2006) described entrepreneurship as the process of conceiving, planning, launching, and innovating a business opportunity into a potentially large undertaking, in a complex and volatile environment. Based of those definitions, entrepreneurship is described in this study as the process of creating, managing, and retaining business opportunities through innovation, while also ensuring that the business is unquestionably profitable.

As far as intention is concerned, it denotes a state of mind that directs a person's attention toward a specific target in order to obtain something. Entrepreneurial intention deals with a person's mindset, which leads to the creation and implementation of a new commercial venture or business concept (Yildırım et al., 2016). An entrepreneurial intention can be thought of as a method for locating information that can be used to achieve the goal of starting a company. As compared to someone who does not want to start a new company, someone with a tendency to do so will have a greater willingness (Muhammadsyah \& Hut, 2016).

In more depth, the entrepreneurial intention is regarded as the first step in developing a long-term business relationship (Lee et al., 2011). Fensi (2018) concurred that entrepreneurial intention is the first step in establishing a longterm company. Entrepreneurial intention stands for the first steps in starting a company. Entrepreneurial intention, according to Walipah and Naim (2016), represents a person's dedication to begin a new company and should be taken into account when learning about the entrepreneurial process and launching a new venture. Entrepreneurial intention, according to Suharti and Sirine (2012), is a central problem that requires attention in understanding the entrepreneurial process. In this case, entrepreneurial intention represents a person's dedication to starting a new company. Based on those definitions, this study defines entrepreneurial intention as the initial step a person will take solidify a business concept that will be carried out in the long term or a desire to create a new business.

Hartigan (2010) stated that "self-efficacy and social support as salient antecedents 
of intention formation to be entrepreneur". The intentions to be an entrepreneur develop from perceptions of desirability, which are affected by emotional and cognitive attitudes (empathy and moral judgment), and from perceptions of feasibility, which are instigated by 'enabling' factors Those factors may be selfefficacy, which implies a self-directed enabling process, and social support, which refers to another directed process and a second enabling force in this process.

\subsection{Entrepreneurial Self-Efficacy (ESE)}

Entrepreneurial self-efficacy is a valuable concept for understanding human behavior. According to studies, it has a significant impact on determining a character's preference, degree of effort, and perseverance (Chen et al., 2004). Entrepreneurial self-efficacy is a method of growing an individual's entrepreneurial capability to acquire confidence and readiness to pursue a career as an entrepreneur, based on perceived self-capability in identifying and pursuing business possibilities, finding new products, managing a business, creating and cultivating business partners, and mental maturity as an entrepreneur (Nguyen, 2020).

According to Yuliatika and Palupi (2017), entrepreneurial self-efficacy is a person's confidence in one's ability to complete a task in order to obtain a particular result. Individuals' self-perceptions of their skills and abilities are the foundation of entrepreneurial self-efficacy. This idea represents a person's innermost thoughts on whether or not they possess the abilities that have been attributed to them (Wilson et al., 2008). According to those definitions, in this study, entrepreneurial self-efficacy is individuals' belief in their abilities and expertise in carrying out entrepreneurial activities. Persons believe that they may run a business and they have entrepreneurial mentality.

\subsection{Social Support (SS)}

Social support is the resource assistance derived from close social relationships with the person receiving assistance (Lestari, 2020). Individuals receive social support in comfort, recognition, rewards, and other types of assistance from groups or other citizens (Sarafino, 2002).

Social support mobilizes psychological resources, aids in emotional burden mastery, and is the most common form of increasing personal resources. Social support is accomplished by supplying one or more of the four main categories of support services, which are shared in an infinite amount, as part of social exchange relationships to achieve specific goals (Gubbins et al., 2020).

Social support is also described as help or support from others, such as friends, relatives, neighbors, colleagues (Rani, 2012). Social support is expected to aid and assist the aspiring entrepreneur in establishing and operating a company ( $\mathrm{Ng} \&$ Jenkins, 2018).

In this study, social support is defined as the assistance provided by the closest people to the individual to be assisted, for example, from friends, siblings, parents, neighbors and others, in the form of assistance, encouragement, and comfort for that person to achieve the goals they wish to attain. 


\section{Methods}

Multiple data collection methods have been used in this preliminary study to improve the quality of the study and provide clear evidence (Guba \& Lincoln, 2000). The methods of data collection were a questionnaire and semi-structured interviews. In this study, the researchers used the purposive sampling method, as according to Tongco (2007), which may be used as a data gathering method in a preliminary study, while a researcher is still determining the feasibility of a proposed sample.

The researchers used an open-ended questionnaire to perform a preliminary survey of 111 students in class 12 and 60 alumni, who graduated within two years of pilot public vocational high schools. In a survey, an open-ended question is one to which the respondent responds in their own terms and to which the respondent is advised to respond. The questions allow for the respondent's spontaneous answers. These questions are usually asked as part of a preliminary investigation (Popping, 2015). The researchers conducted semi-structured interview with three students, who answered in their questionnaire that they wanted to be entrepreneurs.

Mathers et al. (2007) stated that asking open-ended questions allows the researcher to explore in depth. Furthermore, an interview is a flexible and useful data collection tool, that is usually conducted face-to-face to gather data on participant interactions and behavioral interviews, which can help the researcher better understand what is being said (Ryan et al., 2009). Weller et al. (2018) stated that finding and customizing the point where no new knowledge is gained is the primary goal of qualitative interviews or open-ended questions (thematic saturation). It can be used in conjunction with other interview techniques, or on its own, to delve deeper into a subject.

Because of the Covid-19 pandemic, this study conducted interviews online with the Zoom meeting software application. Video recording from the Zoom application was also undertaken in the interview process. Eynon et al. (2008) stated that using interviews and surveys in the online world has recently become very common. The video recording took place with the participants' permission and was only be used to recollect the participants' answers, as required during the data analysis. Conducting interviews involves applying various skills, such as note-taking, intense listening, and proper preparation (Qu \& Dumay, 2011).

By integrating the two data collection approaches, Guba and Lincoln (2000) were able to improve the technique and provide consistent evidence. It allows for triangulation to enhance the data and findings' reliability and validity.

This paper uses thematic analysis with data management using inductive coding. The researchers read, interpreted and found themes and sub-themes that were relevant to this study. Braun and Clarke (2006) stated that the concepts found using an inductive approach are closely linked to the data and may have no connection to the specific questions asked of the participants. Inductive analysis is the method of coding data without attempting to fit it into a pre-existing coding 
framework or the researcher's analytic assumptions. This form of thematic analysis is data-driven in this way.

\section{The Preliminary Study's Findings and Discussions}

Firstly, the researchers explored the demographic samples (for students in class 12 and with graduates within two years after graduation). Based on the results of the questionnaire of 111 students in class 12 (Figure 1), it showed that their plan after graduation as to become employees $(45.05 \%)$, entrepreneurs $(9.00 \%)$, and others $(45.95 \%)$.



Figure 1: Students' plan after graduation

Likewise, a preliminary questionnaire of 60 alumni (Figure 2) showed that their current work is of employees (36.67\%), entrepreneurs $(1.67 \%)$, and unemployed $(61.66 \%)$.

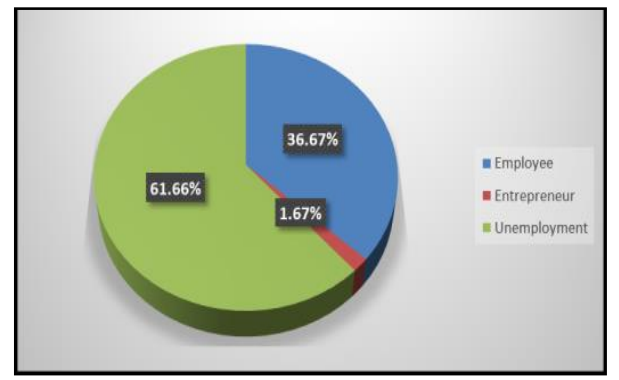

Figure 2: Current work of alumni

Based on the findings, the researchers concluded that the entrepreneurial intention or desire to be an entrepreneur, in the pilot public vocational high schools, is low, as only $9 \%$ of students want to be an entrepreneur after graduation, and $1.67 \%$ of graduates are currently working as entrepreneurs. Based on those findings, the researchers asked 111 students in class 12 why they had a low entrepreneurial intention.

The researchers analyzed the data from the questionnaire results and interview transcripts to extract the themes and sub-themes. Creswell's five steps of data analysis were used: i) organizing and prepare preparing data, ii) reading through all data, iii) coding the data, iv) interrelating the themes, and v) interpreting the meaning of themes (Creswell, 2014). The researchers followed the steps and found the various themes and sub-themes from the questionnaire and interview results. The data and transcript were read several times before being grouped into 
information and knowledge units. The study's goal was to investigate the main factors that influence entrepreneurial intention. As a result, the coding step was carried out to highlight the most occuring (repeatedly mentioned) and relevant ideas that were thought to be important components of themes. The researchers found codes relating to the preliminary data from the questionnaire and interview. However, the researchers only took the relevant codes to develop the themes and sub-themes of this study.

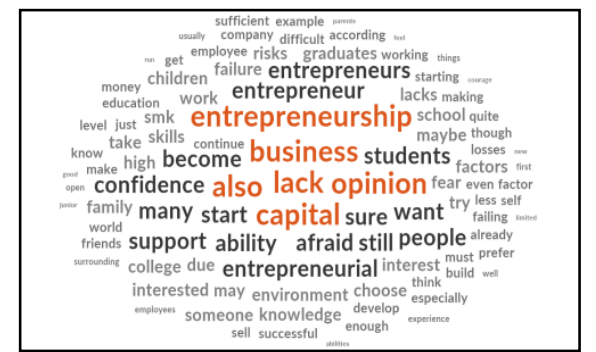

Figure 3: Word cloud for preliminary data

Regardless of the diversity of responses given by the 111 students in class 12, 60 alumni, and three participants about entrepreneurial intention, the review of questionnaire results and interview transcripts revealed several themes and subthemes, as shown in Figure 4, Table 1, Table 2, and Table 3. Figure 4 shows that several themes, discovered from the preliminary data (questionnaire and interview), as factors that influenced the low entrepreneurial intention of students and alumni.



Figure 4: Compared by number of items coded for preliminary data 
Table 1: Various themes and sub-themes extracted from the questionnaire (60 alumni)

\begin{tabular}{|c|c|c|c|c|c|}
\hline $\begin{array}{c}\text { GENERAL } \\
\text { STATEMENT }\end{array}$ & $\begin{array}{c}\text { SUB- } \\
\text { THEMES }\end{array}$ & $\begin{array}{l}\text { SUPPORTING } \\
\text { LITERATURE }\end{array}$ & $\begin{array}{l}\text { NUMBER OF } \\
\text { RESPONSES }\end{array}$ & THEMES & $\%$ \\
\hline $\begin{array}{l}\text { Feeling lack of } \\
\text { entrepreneurial } \\
\text { skills }\end{array}$ & Own skill & $\begin{array}{l}\text { (Ibrahim \& Mas'ud, } \\
\text { 2016) }\end{array}$ & 11 & \multirow{6}{*}{ ESE } & \multirow{6}{*}{83.33} \\
\hline Not confident & $\begin{array}{l}\text { Personal } \\
\text { traits }\end{array}$ & $\begin{array}{l}\text { (Şahin et al., 2019; } \\
\text { İrengün \& Arıkboğa, } \\
\text { 2015) }\end{array}$ & 15 & & \\
\hline Fear of failure & & (Şahin et al., 2019) & 9 & & \\
\hline $\begin{array}{l}\text { Lack of } \\
\text { entrepreneurial } \\
\text { knowledge }\end{array}$ & \multirow{2}{*}{$\begin{array}{l}\text { Gained } \\
\text { knowledge }\end{array}$} & (Rowley, 2000) & 7 & & \\
\hline $\begin{array}{l}\text { Not able to } \\
\text { overcome } \\
\text { obstacles }\end{array}$ & & (Rowley, 2000) & 6 & & \\
\hline $\begin{array}{l}\text { Have the ability } \\
\text { to deal with } \\
\text { investors }\end{array}$ & $\begin{array}{l}\text { Initiating } \\
\text { investor } \\
\text { relationship }\end{array}$ & $\begin{array}{l}\text { (Johanna Mair, } \\
\text { Hartigan, 2010) }\end{array}$ & 2 & & \\
\hline $\begin{array}{l}\text { A sense of trust / } \\
\text { concern from the } \\
\text { environment }\end{array}$ & $\begin{array}{l}\text { Emotional } \\
\text { support }\end{array}$ & $\begin{array}{lrr}\text { (Marta \& } & \text { Kurniasari, } \\
2019 ; & \text { Mair } \quad \text { } \\
\text { Hartigan, } & 2010 ; \\
\text { Sequeira et al., } & \text { 2007) }\end{array}$ & 8 & \multirow{3}{*}{ SS } & \multirow{3}{*}{60} \\
\hline $\begin{array}{l}\text { Financial } \\
\text { support }\end{array}$ & \multirow[t]{2}{*}{$\begin{array}{l}\text { Tangible } \\
\text { support }\end{array}$} & $\begin{array}{l}\text { (Marta \& } \text { Kurniasari, } \\
\text { 2019; Aldrich \& } \\
\text { Zimmer, } \\
\text { Rahaman et al., 2020) }\end{array}$ & 27 & & \\
\hline Goods support & & $\begin{array}{l}\text { (Marta \& Kurniasari, } \\
\text { 2019) }\end{array}$ & 1 & & \\
\hline $\begin{array}{l}\text { Preferring to } \\
\text { work }\end{array}$ & -NA- & (Wijaya \& Mada, 2008) & 6 & $\begin{array}{l}\text { Choosing } \\
\text { to work }\end{array}$ & 10 \\
\hline College & -NA- & (Lopa et al., 2018) & 1 & $\begin{array}{l}\text { Continue } \\
\text { to study }\end{array}$ & 1.67 \\
\hline Lack practices & -NA- & $\begin{array}{l}\text { (Perwita \& Khotimah, } \\
\text { 2015) }\end{array}$ & 4 & $\begin{array}{c}\text { Lack of } \\
\text { entrepre- } \\
\text { neurship } \\
\text { practices } \\
\text { in school }\end{array}$ & 6.67 \\
\hline Have no time & -NA- & (Ahmad et al., 2004) & 1 & $\begin{array}{l}\text { Lack of } \\
\text { time }\end{array}$ & 1.67 \\
\hline
\end{tabular}

Source: The data was processed by the researchers.

Note: -NA- written when there is no sub-theme. 
Table 2: Various themes and sub-themes extracted from the questionnaire (111 students in class 12)

\begin{tabular}{|c|c|c|c|c|c|}
\hline STATEMENT & $\begin{array}{c}\text { SUB- } \\
\text { THEMES }\end{array}$ & $\begin{array}{l}\text { SUPPORTING } \\
\text { LITERATURE }\end{array}$ & $\begin{array}{l}\text { NUMBER OF } \\
\text { RESPONSES }\end{array}$ & THEMES & $\%$ \\
\hline $\begin{array}{l}\text { Feeling lack of } \\
\text { entrepreneurial } \\
\text { skills }\end{array}$ & Own skill & $\begin{array}{l}\text { (Ibrahim } \\
\text { Mas'ud, 2016) }\end{array}$ & 37 & \multirow{5}{*}{ ESE } & \multirow{5}{*}{74.77} \\
\hline Not confident & $\begin{array}{l}\text { Personal } \\
\text { traits }\end{array}$ & $\begin{array}{l}\text { (Şahin et al., 2019; } \\
\text { İrengün \& } \\
\text { Arıkboğa, 2015) }\end{array}$ & 18 & & \\
\hline Fear of failure & & (Şahin et al., 2019) & 15 & & \\
\hline $\begin{array}{l}\text { Lack of } \\
\text { entrepreneurial } \\
\text { knowledge }\end{array}$ & \multirow{2}{*}{$\begin{array}{l}\text { Gained } \\
\text { knowledge }\end{array}$} & (Rowley, 2000) & 9 & & \\
\hline $\begin{array}{l}\text { Not able to } \\
\text { overcome } \\
\text { obstacles }\end{array}$ & & (Rowley, 2000) & 4 & & \\
\hline $\begin{array}{l}\text { A sense of trust / } \\
\text { concern from the } \\
\text { environment }\end{array}$ & $\begin{array}{l}\text { Emotional } \\
\text { support }\end{array}$ & $\begin{array}{l}\text { (Marta \& } \\
\text { Kurniasari, 2019; } \\
\text { Mair \& Hartigan, } \\
\text { 2010; Sequeira et } \\
\text { al., 2007) }\end{array}$ & 18 & \multirow[b]{2}{*}{ SS } & \multirow[b]{2}{*}{46.85} \\
\hline Financial support & $\begin{array}{l}\text { Tangible } \\
\text { support }\end{array}$ & $\begin{array}{lr}\text { Marta } & \& \\
\text { Kurniasari, } & 2019 ; \\
\text { Aldrich } & \& \\
\text { Zimmer, } & 1986 ; \\
\text { Rahaman } & \text { et al., } \\
2020) & \end{array}$ & 34 & & \\
\hline $\begin{array}{l}\text { Preferring to } \\
\text { work }\end{array}$ & -NA- & $\begin{array}{l}\text { (Wijaya \& Mada, } \\
\text { 2008) }\end{array}$ & 15 & $\begin{array}{l}\text { Choosing } \\
\text { to work }\end{array}$ & 13.51 \\
\hline College & -NA- & (Lopa et al., 2018) & 13 & $\begin{array}{l}\text { Continue } \\
\text { to study }\end{array}$ & 11.71 \\
\hline Have no time & -NA- & $\begin{array}{l}\text { (Ahmad et al., } \\
2004)\end{array}$ & 2 & $\begin{array}{l}\text { Lack of } \\
\text { time }\end{array}$ & 1.80 \\
\hline Not prestigious & -NA- & (Rusdiana, 2018) & 3 & $\begin{array}{l}\text { Less } \\
\text { prestigiou } \\
\text { s job }\end{array}$ & 2.70 \\
\hline
\end{tabular}

Source: The data was processed by the researchers.

Note: -NA- written when there is no sub-theme. 
Table 3: Various themes and sub-themes extracted from the interview (three students)

\begin{tabular}{|c|c|c|c|c|}
\hline STATEMENT & SUB-THEMES & $\begin{array}{l}\text { SUPPORTING } \\
\text { LITERATURE }\end{array}$ & $\begin{array}{l}\text { NUMBER OF } \\
\text { RESPONSES } \\
\end{array}$ & THEMES \\
\hline Have motivation & $\begin{array}{l}\text { Entrepreneurial } \\
\text { determination }\end{array}$ & $\begin{array}{l}\text { (Al-Jubari et al., } \\
\text { 2019) }\end{array}$ & 1 & EI \\
\hline Not confident & \multirow[t]{2}{*}{ Personal traits } & $\begin{array}{l}\text { (Şahin et al., 2019; } \\
\text { İrengün } \\
\text { Arıkboğa, 2015) }\end{array}$ & 2 & \multirow{4}{*}{ ESE } \\
\hline Fear of failure & & (Şahin et al., 2019) & 2 & \\
\hline $\begin{array}{l}\text { Lack of } \\
\text { entrepreneurial } \\
\text { knowledge }\end{array}$ & \multirow{2}{*}{$\begin{array}{l}\text { Gained } \\
\text { knowledge }\end{array}$} & (Rowley, 2000) & 1 & \\
\hline $\begin{array}{l}\text { Not capable of } \\
\text { overcoming } \\
\text { obstacles }\end{array}$ & & (Rowley, 2000) & 1 & \\
\hline $\begin{array}{l}\text { Feelings of } \\
\text { appreciation / } \\
\text { awarding }\end{array}$ & \multirow[b]{2}{*}{$\begin{array}{l}\text { Emotional } \\
\text { support }\end{array}$} & $\begin{array}{lr}\text { Marta } & \& \\
\text { Kurniasari, } & 2019 ; \\
\text { Klyver et al., 2018) }\end{array}$ & 1 & \multirow{4}{*}{ SS } \\
\hline $\begin{array}{l}\text { Trust / care from } \\
\text { the environment }\end{array}$ & & $\begin{array}{l}\text { (Marta \& } \\
\text { Kurniasari, 2019; } \\
\text { Mair \& Hartigan, } \\
\text { 2010; Sequeira et al., } \\
\text { 2007) }\end{array}$ & 1 & \\
\hline Financial support & Tangible support & $\begin{array}{l}\text { (Marta \& } \\
\text { Kurniasari, 2019; } \\
\text { Aldrich \& Zimmer, } \\
\text { 1986; Rahaman et } \\
\text { al., 2020) }\end{array}$ & 1 & \\
\hline $\begin{array}{l}\text { Helpful } \\
\text { information }\end{array}$ & $\begin{array}{l}\text { Informational } \\
\text { support }\end{array}$ & $\begin{array}{lr}\text { Marta } & \& \\
\text { Kurniasari, } & 2019 ; \\
\text { Rahaman et al., } \\
2020)\end{array}$ & 2 & \\
\hline
\end{tabular}

Source: The data was processed by the researchers.

The researchers summarized the codes into seven themes based on the study, with several essential sub-themes.

1. Entrepreneurial self-efficacy (ESE)

The analysis results from questionnaire to 60 alumni suggested that the theme of entrepreneurial self-efficacy is developed from four sub-themes (own skill, personal traits, gained knowledge, and initiating investor relationship). In the analysis results from the questionnaire to 111 students in class 12, the researchers found that the theme of entrepreneurial self-efficacy is developed from three subthemes (own skill, personal traits, and gained knowledge). From the analysis results from the interviews with three students, the researchers found that the theme of entrepreneurial self-efficacy is developed from two sub-themes (personal traits and gained knowledge). The researchers concluded that the theme entrepreneurial self-efficacy is developed from four sub-themes (own skill, personal traits, gained knowledge, and initiating investor relationship). 




Figure 5: Compared by number of items coded for ESE

\section{Social support (SS)}

The analysis results from the questionnaire, distributed to 60 alumni, found that theme of social support was developed from two sub-themes (emotional support and tangible support). The analysis results from questionnaire to 111 students in class 12 , found that the theme social support was developed from two sub-themes (emotional support and tangible support). From the analysis results of the interview with three students, the researchers found that the theme of social support was developed from three sub-themes (emotional support, informational support, and tangible support). The researchers concluded that the theme of social support developed from three sub-themes, which are emotional support, informational support, and tangible support.



Figure 6: Compared by number of items coded for SS

\section{Choosing to work}

The analysis results from the interview with three students and the questionnaire to 111 students and 60 alumni found 21 statements of preferring to work as a factor of low entrepreneurial intention. This finding was supported by Wijaya and Mada (2008), who found that Indonesians tend to work as private or public workers. Implicitly, formal and non-formal education in Indonesia still does not focus on entrepreneurship. 


\section{Continue to study}

The analysis results from the interview with three students and the questionnaire to 111 students and 60 alumni found that the 14 statements of continuing to colleges are factors of low entrepreneurial intention. Several factors strongly influence vocational high school graduates' desire to continue their studies at universities. Students feel that they lack skills, such as goods marketing skills, because of this. The students' interest is more focused on continuing their studies to increase their skills by continuing their studies to college (Lopa et al., 2018).

\section{Lack of entrepreneurship practices in school}

The analysis results from the interview with three students and the questionnaire to 111 students and 60 alumni found that the statements of lack of practices and more theories in class are factors of low entrepreneurial intention. As Perwita and Khotimah (2015) expounded, internal theory classes still dominate entrepreneurship learning. The balance between theory and practice in learning is still lacking.

\section{Lack of time}

The analysis results from the interview with three students and the questionnaire to 111 students and 60 alumni found that a lack of time to conduct business is among the factors of low entrepreneurial intention. They still thought that entrepreneurs are people who devote time and effort to create something different. They risk their time, money, and comfort to develop business (Ahmad et al., 2004). Musyadar and Iwang Gumilar (2019) also found that entrepreneurship requires hard work and a long time. Many entrepreneurs work alone, such as buying, processing, sales, and bookkeeping. Many are impatient because it takes a long time, so that there might be a chance that someone withdraws from entrepreneurship.

\section{Less prestigious job}

The analysis results from the interview with three students and the questionnaire to 111 students and 60 alumni found that the statement of an entrepreneur not being a prestigious job is a factor of low entrepreneurial intention. This is supported by Rusdiana (2018), who said that the facts show that the entrepreneurial spirit among graduates is still lacking because, in general, they expect a traditional culture to last, namely working in the formal sector as whitecollar workers, who are considered more prestigious. Similarly, Burton et al. (2016) stated that an individual may enter entrepreneurship as an end state, but many find that they cannot succeed, and this work becomes a last choice. Most graduates like to hunt for employment rather than creating or doing entrepreneurial activities because this work is not a chosen career (Mohamad et al., 2014).

The results of the themes based on the questionnaires for students and alumni are displayed. As shown in Figure 7, the reasons for low entrepreneurial intention are low entrepreneurial self-efficacy $(74.78 \%)$, lack of social support $(46.85 \%)$, preferring to work (13.51\%), continue to study (11.71\%), less prestigious job $(2.7 \%)$, and lack of time $(1.8 \%)$. 


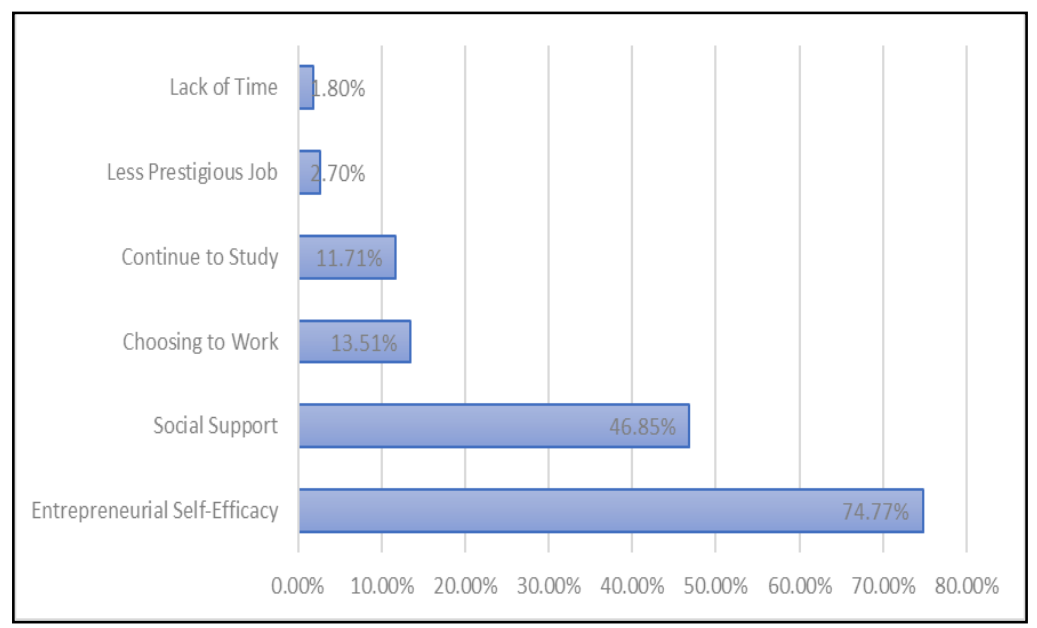

Figure 7: Factors of low entrepreneurial intention of students

According to the questionnaire results of 60 alumni, in Figure 8, the reasons for low entrepreneurial intention are low entrepreneurial self-efficacy $(83.33 \%)$, lack of social support $(60 \%)$, preferring to work $(10 \%)$, lack of entrepreneurship practices in school $(6.67 \%)$, continuing to study $(1.67 \%)$, and lack of time $(1.67 \%)$.

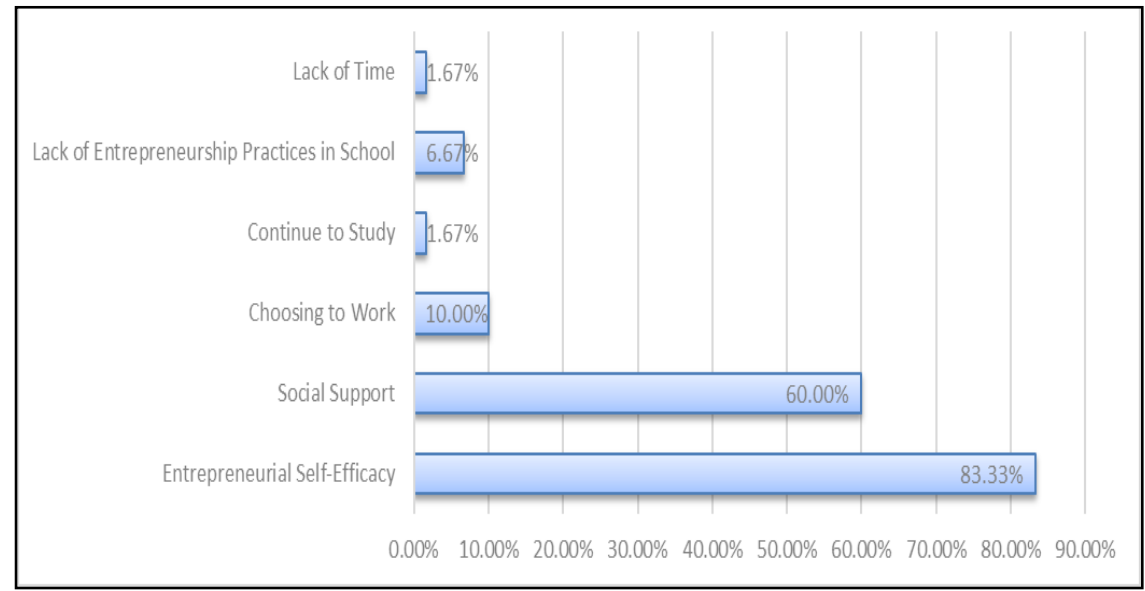

Figure 8: Factors of low entrepreneurial intention of alumni

From the questionnaire results of students in class 12 and alumni, the factors that influence the problem of entrepreneurial intention are entrepreneurial selfefficacy, social support, choosing to work, continue to study, lack of time, lack of entrepreneurship practice in school, and less prestigious job.

The researchers conducted interviews to explain the constructs' role in this analysis, namely an independent construct or a moderator construct, based on the two highest factors or themes of low entrepreneurial intention (entrepreneurial self-efficacy and social support). Shonubi et al. (2016) presented that moderators could be considered an independent factor in the study. A moderator is an independent variable that influences the intensity or direction of the relationship between two or more independent variables and an outcome variable. The 
researchers would investigate these constructs further, via interviews, as independent and moderator constructs in the problems that arise in this study.

In response to the questionnaire findings, the researchers conducted interviews with three students who wanted to be entrepreneurs after graduation. This interview aimed to learn about respondents' personal experiences with obstacles to their entrepreneurial intention or desire to create a new business. These limitations were discovered to be caused by low entrepreneurship self-efficacy, lack of social support, and Indonesians' tendency to underestimate careers as entrepreneurs.

From the interview results, it is known that the respondents' entrepreneurial selfefficacy is low. This is evident in the responses: "The reason I' $m$ not sure is because I have challenges where my enthusiasm for starting or learning entrepreneurship hasn't faded"; "Fear of failure with the business that will be run later"; and "Friends who aren't encouraging make me feel uncertain." Thus, it seemed that they were uncertain about their ability and skills to develop new business.

Furthermore, based on the results of the interviews, the researchers discovered that the support from relatives, friends, or the surrounding community is generally negative, as shown by the percentage of respondents who stated that they lacked social support $(46.85 \%$ of a total of 111 respondents, as shown in Figure 3). Wijaya and Mada (2008) supported this claim, stating that Indonesians prefer to work as private or public employees. Indirectly, Indonesian formal and non-formal education is still not oriented toward entrepreneurship. In other nations, such as Malaysia, the same thing happened. According to Ismail et al. (2009), parents, siblings, and spouses all play an important role in a person's desire to start a business and they can be positive or negative influence.

Furthermore, the tradition of working for the government or a private company is still rooted in Indonesian society. It has been since school, with entrepreneurship as the last option for finding work (Wijaya et al., 2015). The majority of family social support is still not conducive to the development of entrepreneurial intentions in children. This is in line with a statement from one of the respondents: "The thing that makes me unsure is because, from my family, it is still rare to become entrepreneurs".

The causal impact of entrepreneurial self-efficacy on entrepreneurial intention is dependent on social support, such as emotional support, according to the findings of student interviews. The statements: "Help from friends will make me more confident and willing to collaborate with entrepreneurship", and "The support that is needed is from parents and also myself" exemplify this. The term "myself" can be described as the respondent's entrepreneurial self-efficacy as a result of the support they require. The high sense of self-efficacy for entrepreneurship is supported in this case by social support. The participants' sense of self-efficacy in entrepreneurial activities is still low, based on the responses; participants hope that the environment can help to reinforce the connection between entrepreneurial self-efficacy and entrepreneurial intention. According to the findings, it was expected that social 
support increases the causal impact of entrepreneurial self-efficacy on entrepreneurial intention. The term "moderation" refers to the weakening of a causal effect; however, a moderator may also strengthen the causal effect (Awang, 2015).

At the time of writing, this study has not been fully completed and further analyzed, and it is continuing. The results of this preliminary study, however, can be reported.

\section{Conclusion}

The conclusions of this preliminary study are:

a) This paper presents an ongoing doctoral study exploring the entrepreneurial intention of pilot public vocational high school students for entrepreneurship development programs in Jakarta, Indonesia.

b) The data from the questionnaire, distributed to 111 students and 60 alumni, showed that entrepreneurial intention is low (from their choosing work after graduation and the current work of alumni).

c) Research tool used in this study is NVivo 12.

d) Data from both questionnaire and semi-structured interview revealed several themes and sub-themes. The researchers summarized codes into the themes that were further divided into seven themes (entrepreneurial self-efficacy, social support, choosing to work, continuing to study, lack of entrepreneurship practices in school, lack of time, less prestigious job) based on the study, with several essential sub-themes.

e) The researchers concluded that the theme of entrepreneurial self-efficacy was developed from four sub-themes (own skill, personal traits, gained knowledge, and initiating investor relationship);

f) The researchers concluded that the theme of social support was developed from three sub-themes (emotional support, informational support, and tangible support);

g) The data from the questionnaire to 111 students and 60 alumni suggested that entrepreneurial self-efficacy and social support were the two highest factors that influence entrepreneurial intention.

h) The interviews with the three students implied that social support increases the causal impact of entrepreneurial self-efficacy on entrepreneurial intention.

This study is continuing its next steps to get final results. The study's findings could be of interest to the government, schools, curriculum developers/syllabus designers, and other researchers. The results will enable those relevant parties to determine the entrepreneurial intention needed to prevent and reduce unemployment among vocational high school graduates. Furthermore, it could contribute to curriculum developers/syllabus designers to make a curriculum that enhances students' entrepreneurial intention. The recommendations for further research are to include other variables that are appropriate to be applied in the research.

\section{References}

Ahmad, F. S., Baharun, R., \& Abd Rahman, S. H. (2004). Interest In entrepreneurship: An exploratory study on engineering and technical students in entrepreneurship 
education and choosing entrepreneurship as a career. Journal of Advances in Management Sciences \& Information Systems, Special Issues, 1-45.

Al-Jubari, I., Hassan, A., \& Liñán, F. (2019). Entrepreneurial intention among university students in Malaysia: integrating self-determination theory and the theory of planned behavior. International Entrepreneurship and Management Journal, 15(4), $1323-$ 1342. https://doi.org/10.1007/s11365-018-0529-0

Aldrich, H., \& Zimmer, C. (1986). Entrepreneurship through social networks. In D. Sexton and R. Smilor (Eds.), In The art and science of entrepreneurship. Ballinger Publishing Company.

Asian Trading Economies. (2020, June 26). Unemployment Rate Asia. https:/ / tradingeconomics.com/country-list/unemployment-rate?continent =asia

Awang, Z. (2015). SEM Made Simple: A Gentle Approach To learning Structural Equation Modeling. MPWS Rich Publication Sdn. https:/ /api.semanticscholar.org/CorpusID:64198895

Braun, V., \& Clarke, V. (2006). Using thematic analysis in psychology. Qualitative Research in Psychology, 3(2), 77-101. https://doi.org/10.1191/1478088706qp063oa

Burton, M. D., Sørensen, J. B., \& Dobrev, S. D. (2016). A Careers Perspective on Entrepreneurship. Entrepreneurship Theory and Practice, March, 237-247. https://doi.org/10.1111/etap.12230

Chen, G., Gully, M. S., \& Eden, D. (2004). General self-efficacy and self-esteem: Toward theoretical and empirical distinction between correlated self-evaluations. Journal of Organizational Behavior, 25, 375-395.

Cheung, C. K. (2016). Issues in the future development of business education in Hong Kong secondary curriculum. Cogent Education, 3(1). https://doi.org/10.1080/2331186X.2015.1129688

Creswell, J. W. (2014). Research Design-Qualitative, Quantitative, and Mixed Methods Approaches (4 $4^{\text {th }}$ ed.). SAGE Publications, Inc.

Eynon, R., Fry, J., \& Schroeder, R. (2008). The Ethics of Internet Research. In N. Fielding, R.M. Lee, \& G. Blank (Eds.), The SAGE Handbook of Online Research Methods (pp. 2341). SAGE Publications, Inc.

Fensi, F. (2018). The Influence of Entrepreneurship Education in Growing Interest in Entrepreneurship. Journal of Devotion And Entrepreneurship, 2(1), 1-9.

Guba, E. G., \& Lincoln, Y. S. (2000). Paradigmatic Controversies, Contradictions, and Emerging Confluences. In N. K. Denzin and Y. S. Lincoln (Eds.), Handbook of Qualitative Research (2nd ed., pp. 191-216). Sage.

Genoveva, G. (2020). The Influence of Entrepreneurial Culture on Entrepreneurial among Business Students. Firm Journal of Management Studies, 4(1), 40-56. https://doi.org/10.33021/firm.v4i1.682

Gubbins, M., Harrington, D., \& Hines, P. (2020). Social support for academic entrepreneurship: definition and conceptual framework. Journal of Management Development. https:// doi.org/10.1108/JMD-11-2019-0456

Ibrahim, N. A., \& Mas'ud, A. (2016). Moderating role of entrepreneurial orientation on the relationship between entrepreneurial skills, environmental factors and entrepreneurial intention: A PLS approach. Management Science Letters, 6, 225-236. https://doi.org/10.5267/j.msl.2016.1.005

Indonesian Central Statistics Agency. (2020). Entrepreneurs Data Based on Institutions Level. In Indonesian Central Statistics Agency (p. 5).

İrengün, O., \& Arıkboğa, Ş. (2015). The Effect of Personality Traits on Social Entrepreneurship Intentions: A Field Research. Procedia-Social and Behavioral Sciences, 195, 1186-1195. https:// doi.org/10.1016/j.sbspro.2015.06.172 
Ismail, M., Khalid, S. A., Othman, M., Jusoff, H. K., Rahman, N. A., Kassim, K. M., \& Zain, R. S. (2009). Entrepreneurial Intention among Malaysian Undergraduates. International Journal of Business and Management, 4(10), 54-60. https://doi.org/10.5539/ijbm.v4n10p54

Klyver, K., Honig, B., \& Steffens, P. (2018). Social support timing and persistence in nascent entrepreneurship: Exploring when instrumental and emotional support is most effective. Small Business Economics, 51(3), 709-734. https://doi.org/10.1007/s11187017-9964-5

Lee, L., Wong, P. K., Foo, M. D., \& Leung, A. (2011). Entrepreneurial intentions: The influence of organizational and individual factors. Journal of Business Venturing, 26(1), 124-136.

Lestari, H. D. (2020). Academic Support, Social Support, Environment Support and Eentrepreneurship Education as Contextual Factors. Management And Business Scientific Magazine, 17(1), 38-52.

Linan, F., \& Chen, Y. (2006). Testing the Entrepreneurial Intention Model on a two-country Sample. Documents de Treball, 06/7, 1-37.

Lopa, A. T., Arfandi, A., \& Salim, J. R. E. (2018). Analysis of Student Interest After Graduating From Vocational High School (Case Study of SMK Negeri 2 Parepare). In Jakarta State University Research Institute (Ed.), Proceedings of the National Seminar Dissemination of Research Results through Optimization of Syntax and Intellectual Property Rights (pp. 456-459). State University of Makasar.

Mahendra, A. M., Djatmika, E. T., \& Hermawan, A. (2017). The Effect of Entrepreneurship Education on Entrepreneurial Intention Mediated by Motivation and Attitude among Management Students, State University of Malang, Indonesia. International Education Studies, 10(9), 61. https:// doi.org/10.5539/ies.v10n9p61

Mair, J., \& Hartigan, P. (2010). Social Entrepreneurship. In R. A. Couto (Ed.), Political and Civic Leadership: A Reference Handbook. Sage. https://doi.org/10.4135/9781412979337.n84

Marič, M., Jeraj, M., \& Pavlin, J. (2010). Entrepreneurship as a Solution to the Unemployment Problem. Skola Biznisa, 2. https://doi.org/10.1016/j.jbusvent.2013.05.002

Marta, M. S., \& Kurniasari, D. (2019). The Interaction of Social Support in the Relationship of Entrepreneurial Education, Self-Efficacy and Entrepreneurial Intention. BENEFITS Journal of Management and Business, 4(1), 16-26. https://doi.org/10.23917/benefit.v4i1.7113

Mathers, N., Fox, N., \& Amanda Hunn. (2007). Surveys and questionnaires. In The NIHR RDS for the East Midlands (pp. 1-48). Yorkshire \& the Humber. https://doi.org/10.4324/9780203154281-35

MoEC. (2018). Regulation of the Director General of Primary and Secondary Education Ministry of Education and Culture Number: 07 / D.D5 / Kk / 2018 Concerning Vocational High School/ Madrasah Aliyah Curriculum Structure. In Ministry of Education and Culture (Issue 021, p. 307). http:// psmk.kemdikbud.go.id/konten/3824/struktur-kurikulum-smk-perdirjendikdasmen-no-07dd5kk2018-tanggal-7-juni-2018

MoEC. (2020). Strategic Plan of the Ministry of Education and Culture for the Year 2020-2024. JDIH Kemdikbud.

Mohamad, N., Lim, H., Yusof, N., Kassim, M., \& Abdullah, H. (2014). Estimating the Choice of Entrepreneurship as a Career: The Case of Universiti Utara Malaysia. International Journal of Business and Society, 15(1), 65-80.

Muhammadsyah, A., Puwadi, Fahmi, \& Hut. (2016). The Influence of Social Support on Entrepreneurial Inclination among Business Students in Indonesia. Information 
Management and Business Review, 8(3), 32-46.

Musyadar, A., \& Iwang Gumilar. (2019). Entrepreneurship Concepts And Processes in Entrepreneurship (3rd ed., pp. 128). Bogor Agricultural Development Polytechnic.

$\mathrm{Ng}$, L., \& Jenkins, A. S. (2018). Motivated but not starting: how fear of failure impacts entrepreneurial intentions. Small Enterprise Research, 25(2), 152-167. https://doi.org/10.1080/13215906.2018.1480412

Nguyen, T. T. (2020). Impact of entrepreneurship environmental support factors to university students' entrepreneurship self-efficacy. Management Science Letters, 10(6), 1321-1328. https://doi.org/10.5267/j.msl.2019.11.026

Perwita, D., \& Khotimah, A. K. (2015). Entrepreneurship Practice training at SMKN 3 Purwokerto. Proceedings of the National Seminar on Accounting and Finance Education Developing Sustainable Accounting and Finance Education, 482-493. UNS Press.

Popping, R. (2015). Analyzing Open-ended Questions by Means of Text Analysis Procedures. BMS Bulletin of Sociological Methodology/ Bulletin de Methodologie Sociologique, 128(1), 23-39. https:/ / doi.org/10.1177/0759106315597389

Qu, S. Q., \& Dumay, J. (2011). The qualitative research interview. Qualitative Research in $\begin{array}{lll}\text { Accounting } \quad \text { and } & \text { 238-264. }\end{array}$ https://doi.org/10.1108/11766091111162070

Rahaman, M. A., Ali, M. J., Mamoon, Z. R., \& Al Asheq, A. (2020). Understanding the entrepreneurial intention in the light of contextual factors: Gender analysis. Journal of Asian Finance, Economics and Business, 7(9), 639-647. https://doi.org/10.13106/JAFEB.2020.VOL7.NO9.639

Rani, S. H. B. A. (2012). A Study of Relationship Between Family Support, Role Model and Financial Support Towards Entrepreneurial Inclination Among UUM Non-Business Student. Universiti Utara Malaysia.

Rowley, J. (2000). From learning organisation to knowledge entrepreneur. Journal of Knowledge Management, 4(1), 7-15. https://doi.org/10.1108/13673270010315362

Ryan, F., Coughlan, M., \& Cronin, P. (2009). Interviewing in qualitative research: The oneto-one interview. International Journal of Therapy and Rehabilitation, 16(6), 309-314. https://doi.org/10.12968/ijtr.2009.16.6.42433

Rusdiana, A. (2018). Entrepreneurship Theory and Practice (2nd ed.). Pustaka Setia.

Şahin, F., Karada ğ, H., \& Tuncer, B. (2019). Big five personality traits, entrepreneurial selfefficacy and entrepreneurial intention: A configurational approach. International Journal of Entrepreneurial Behaviour and Research, 25(6), 1188-1211. https://doi.org/10.1108/IJEBR-07-2018-0466

Sarafino, E. P. (2002). Health psychology biopsychosocial interactions. John Wiley \& Sons, Inc,

Sequeira, J., Mueller, S. L., \& McGee, J. E. (2007). The influence of social ties and selfefficacy in forming entrepreneurial intentions and motivating nascent behavior. Journal of Developmental Entrepreneurship, 12(3), 275.

Shonubi, O. A., Abdullah, N., Hashim, R., \& Hamid, N. B. A. B. (2016). Recognition and Appreciation and the Moderating Role of Self-esteem on Job Satisfaction and Performance among IT Employees in Melaka. J. of Health Science, 4(5), 221-227. https://doi.org/10.17265/2328-7136/2016.05.001

Suharti, L., \& Sirine, H. (2012). Factors That Affect Entrepreneurial Intention (Entrepreneurial Intention). Jurnal Manajemen Dan Kewirausahaan, 13(2). https://doi.org/10.9744/jmk.13.2.124-134

Tongco, M. D. C. (2007). Purposive sampling as a tool for informant selection. Ethnobotany Research and Applications, 5, 147-158. https://doi.org/10.17348/era.5.0.147-158

Walipah, W., \& Naim, N. (2016). Factors Affecting Student Entrepreneurial Intentions. $\begin{array}{llll}\text { Journal of } & \text { Modernized }\end{array}$ 
https://doi.org/10.21067/jem.v12i3.1461

Weller, S. C., Vickers, B., Bernard, R., Blackburn, A. M., Borgatti, S., Gravlee, C. C., \& Johnson, J. C. (2018). Open-ended interview questions and saturation. PLoS ONE, 13(6), 1-18. https://doi.org/10.1371/journal.pone.0198606

Wijaya, T., \& Mada, U. G. (2008). Study of Empirical Model of Entrepreneurial Behavior of SMEs in DIY and Central Java. Journal of Management and Entrepreneurship (Journal of Management and Entrepreneurship), 10(2), 93-104-104. https:// doi.org/10.9744/jmk.10.2.pp.93-104

Wijaya, T., Nurhadi, N., \& Kuncoro, A. M. (2015). Student entrepreneurial intentions: Risktaking perspective. Business Strategy Journal, 19(2), 109-123. https://doi.org/10.20885/jsb.vol19.iss2.art2

Yuliatika, D., Rahmawati, S. W., \& Palupi, S. R. (2017). Self Efficacy and Achievement Motivation of Students of SMA Negeri 7 Purworejo. Psychology Journal, 5(2), 59. 